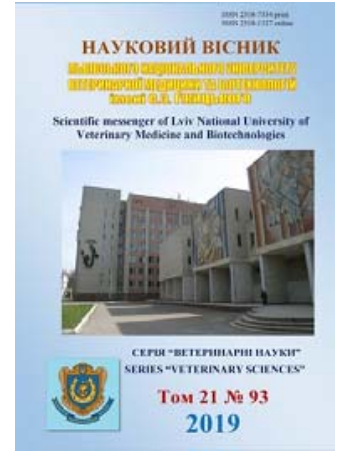

Науковий вісник Львівського національного університету
ветеринарної медицини та біотехнологій імені С.З. Гжицького. Серія: Ветеринарні науки

Scientific Messenger of Lviv National University of Veterinary Medicine and Biotechnologies. Series: Veterinary sciences

ISSN 2518-7554 print ISSN 2518-1327 online doi: $10.32718 /$ nvlvet9321

http://nvlvet.com.ua

\title{
The concentration of insuline-like growth factor in colostrum, milk and plasma of cows
}

\author{
D.V. Hrudetska, M.R. Simonov, O.O. Dashkovskyy
}

Stepan Gzhytskyi National University of Veterinary Medicine and Biotechnologies Lviv, Ukraine

Article info

Received 07.02.2019

Received in revised form 13.03.2019

Accepted 14.03.2019

Stepan Gzhytskyi National University of Veterinary Medicine and Biotechnologies Lviv, Pekarska Str., 50, Lviv, 79010, Ukraine. Tel.: +38-068-519-87-07 E-mail:dhrudetska@gmail.com
Hrudetska, D.V., Simonov, M.R., \& Dashkovsky, O.O. (2019). The concentration of insuline-like growth factor in colostrum, milk and plasma of cows. Scientific Messenger of Lviv National University of Veterinary Medicine and Biotechnologies. Series: Veterinary sciences, 21(93), 121124. doi: $10.32718 /$ nvlvet 9321

Recently, a significant amount of data has been reported indicating on the link between consumption of dairy products and development of oncological diseases. This could be explained by the presence in milk of various hormones, particularly insulin-like growth factor (IGF). This hormone is a mediator between somatotropin and tissues. In response to the increase of the blood level of growth hormone, hepatocytes begin actively synthesize the IGF, which accelerates the rate of the metabolism, including those of onco-cells. The majority of studies relate to humane medicine, and data on the dependence of IGF milk levels on breed, period of lactation, diet, physiological, and clinical status of an animal are lacking. Taking this into consideration, the purpose of this study was to analyze the concentration of insulin-like factor in colostrum, milk of cows and blood plasma at various stages of lactation. Study was performed on cows of Ukrainian blackand-white dairy breed in their from second to fifth lactation with milk yield 5100-5700 kg per previous lactation. Concentration of IGF was detected in colostrum, milk and plasma of cows, using enzyme immunoassay. Obtained material gives evidence that the highest IGF level is present in colostrum. After that hormone concentration decreases up to 10-14 day of lactation. High level of IGF in colostrum might be associated with necessity to stimulate metabolism of calves in early postnatal period of ontogenesis. Immediately after calving plasma level of IGF decreases. The highest level was observed on 10-14 th days of lactation. Taking into consideration physiological function of the given hormone, there is no univocal explanation of the decrease of its plasma level in cows at the beginning of lactation. This could be associated with energy deficit, physiological condition of animals or with developing of lactation dominant and levels of other hormones. Potential of further research lies in investigation of the dependence of the IGF level in the secretion of the mammary gland on productivity, breed, age and diet of animals.

Key words: food safety, hormones, oncological diseases, lactation.

\section{Концентрація інсуліноподібного фактору росту в молозиві, молоці та плазмі крові корів}

\author{
Д.В. Грудецька, М.Р. Сімонов, О.О. Дашковський \\ Львівський національний університет ветеринарної медицини та біотехнологій імені С.3. Гюицького, \\ м. Львів, Україна
}

Останнім часом з'явилася значна кількість даних, які вказують на існування зв 'язку між споживанням молочних продуктів та розвитком онкологічних захворювань. Пояснюється ие наявністю у молоці низки гормонів, зокрема інсуліноподібного фактору росту (ІФР). Даний гормон є посередником між соматотропіном та тканинами. У відповідь на зростання рівня гормону росту в крові гепатоцити починають активно синтезувати IФР, котрий пришвидшує активність метаболізму, в тому числі й онкоклітин. Більшість досліджень стосуються гуманної медицини, а даних щуодо залежності рівня ІФР у молоці від породи, періоду лактації, раціону, фізіологічного, клінічного стану тварини є обмаль. Виходячи з изього метою даної роботи було вивчити концентрацію інсуліноподібного фактору в молозиві, молоці корів та плазмі крові на різних етапах лактації. Досліди проводили на коровах чорно-рябої української молочної породи, 2-5 лактації, продуктивністю 5100-5700 кг молока за попередню лактацію. У моло- 
зиві, молоці та плазмі крові корів досліджували концентрацію ІФР за допомогою імуно-ферментного методу. Отриманий фактичний матеріал свідчить про те, щчо найвищий рівень ІФР реєструється у молозиві. Далі концентрація гормону вірогідно (Р < 0,01) знижується до 10-14 доби лактаиії. Високий рівень ІФР у молозиві може бути пов'язаний з необхідністю стимулювання метаболізму в телят у ранній постнатальний період онтогенезу. У плазмі крові корів встановлено зниження рівня ІФР відразу після отелення. Найвища концентрація спостерігалася на 10-14 доби лактації. Зниження рівня інсуліноподібного фактору росту у плазмі крові корів на початку лактації, враховуючи фізіологічні функиї даного гормону, однозначно пояснити неможливо. Це може бути пов'язано як з енергетичним дефіцитом чи фізіологічним станом тварин, так $і$ з формуванням лактаційної домінанти та рівнем інших гормонів. Перспектива подальших досліджень полягає у досліджені залежності рівня ІФР у секреті молочної залози від продуктивності, породи, віку та годівлі тварини.

Ключові слова: безпека продуктів харчування, гормони, онкозахворювання, лактація.

Ветуп

Безперечно, молоко та молочні продукти - надзвичайно важливі компоненти нашого раціону, оскільки $\epsilon$ важливим джерелом повноцінних протеїнів, поліненасичених жирних кислот, фосфатидів, мінеральних речовин, вітамінів. Молоко забезпечує потребу організму людини у жиророзчинних вітамінах на 20$30 \%$, у вітамінах $\mathrm{B}_{2}$ i $\mathrm{B}_{6}-$ на $70 \%$, а у вітаміні $\mathrm{B}_{12}-$ майже на $100 \%$. Варто зазначити, що всі речовини у молоці перебувають в оптимальному співвідношенні. Однак занепокоєння викликає ряд публікацій (Rogers et al., 2006; Duarte-Salles et al., 2014; Frezza et al., 2018; Rieunier et al., 2019), котрі пов'язують виникнення онкологічних захворювань зі споживанням молока та молочних продуктів. Пояснюється це наявністю у молоці низки гормонів, зокрема інсуліноподібного фактору росту. Так, були встановлені потенційні механізми, що лежать в основі зав'язків між споживанням молока та розвитком проліферативних процесів у передміхуровій залозі (Park et al., 2014; Harrison et al., 2017). Інші дослідники (Kleinberg \& Barcellos-Hoff, 2011; Nielsen et al., 2011; Braak et al., 2015) показують, що інсуліноподібні молекули з посиленою мітогенною сигналізацією збільшують ризик розвитку раку молочної залози. Також існують дані (Um et al., 2017), котрі пов'язують рівень інсуліноподібного фактору 3 розвитком колоректального раку.

Інсуліноподібний фактор росту є найважливішим ендокринним посередником дії соматотропного гормону, тому його також називають соматомедином (Partridge et al., 2011; Kim, 2014; Thornton et al., 2015). У периферичних тканинах саме соматомедин забезпечує практично всі фізіологічні ефекти соматотропного гормону. Крім цього, соматомедин забезпечує зворотний зв'язок тканин з гіпоталамусом і гіпофізом. Вперше цей гормон був описаний у 1957 році (Salmon \& Daughaday, 1957), однак $з$ того часу активно досліджувався лише у гуманній медицині. Зазначений тканинний гормон синтезується гепатоцитами печінки у відповідь на подразнення специфічних рецепторів. У тканинах практично вся дія соматотропного гормону забезпечується ІФР. 3 печінки соматомедин потрапляє в кровотік, а звідти, завдяки посередництву протеїнівпереносників, в тканини й органи (Frysaka et al., 2015).

Виходячи з цього метою даної роботи було вивчити концентрацію інсуліноподібного фактору в молозиві, молоці та плазмі крові корів на різних етапах лактації.

\section{Матеріал і методи досліджень}

Матеріалом для досліджень були корови чорнорябої української молочної породи, 2-5 лактації, продуктивністю 5100-5700 кг молока за попередню лактацію. Відбір проб секрету молочної залози та плазми крові було проведено протягом лютого-березня. Молоко відбирали під час ранішнього доїння у стерильні ємності. Кров отримували з яремної вени у стерильні пробірки з гепарином. Далі молоко осаджували 0,1 н соляною кислотою 3 подальшим центрифугуванням (3 тис. об/хв протягом 15 хв) та видаленням жиру. Для отримання плазми кров відразу центрифугували при трьох тис. об./хв. Молозиво відбирали на 1-3 добу лактації, молоко на 10-14 та 30-40 добу лактації а кров за 7-10 діб до отелення, на 1-3, 10-14 та 30-40 добу лактації. В отриманих пробах досліджували концентрацію інсуліноподібного фактору росту методом імуно-ферментного аналізу із використанням тест-наборів фірми “DRG” (Німеччина).

Відбір проб крові, молозива і молока проводили з урахуванням "Загальних етичних принципів експериментів на тваринах" (Україна, 2001) та згідно з положеннями "Свропейської конвенції про захист хребетних тварин, які використовуються для експериментальних та інших цілей” (Страсбург, 1985).

Одержані цифрові дані опрацьовували в програмі Excel, визначаючи середню арифметичну величину (M), статистичну помилку середньої арифметичної величини (m), вірогідність різниці між середніми арифметичними двох варіаційних рядів $(\mathrm{P}<)$ та ступінь кореляції між показниками (r).

\section{Результати досліджень}

Проведені дослідження секрету молочної залози показали найвищий рівень ІФР у молозиві (рис. 1). На 10-14 добу лактації концентрація гормону в молоці знизилася у 14 разів, а на 30-40 добу - у 8,6 разів $(\mathrm{P}<0,01)$. На 30-40 добу лактації рівень ІФР був дещо вищим, порівняно із 10-14 добою, однак різниця була не вірогідною. Варто звернути увагу на широкі ліміти показника в межах однієї групи тварин. Так, на 1-3 добу лактації концентрація гормону в секреті коливалася в межах від 248,0 до 1028,1 нг/мл, на 10 14 - від 36,1 до 75,2, а на 30-40 добу - від 55,0 до 101,3 нг/мл. 


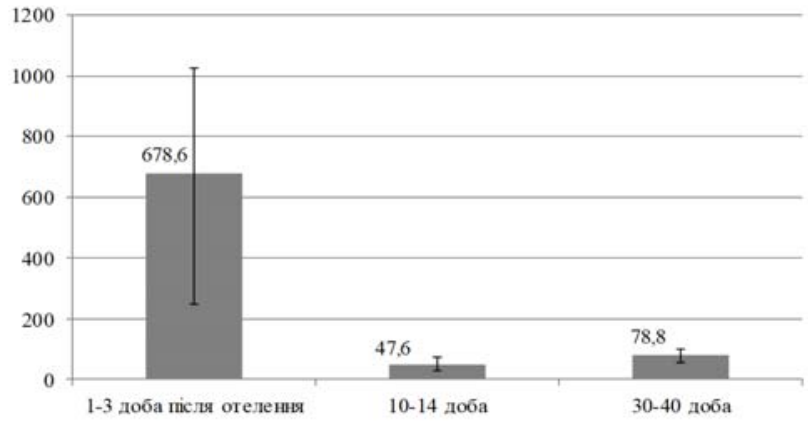

Рис. 1. Концентрація інсуліноподібного фактору росту у секреті молочної залози корів, нг/мл; $\mathrm{n}=10$

Отримані результати показали, що у плазмі крові корів після отелення, порівняно із сухостійними, знизилася концентрація інсуліноподібного фактору росту (рис. 2). Так, порівняно зі 7-10 добою до отелення, на 1-3 добу лактації, його концентрація знизилася на $29,3 \%$ ( $>$ < 0,05). В подальшому (на 10-14 добу) встановлено вірогідне $(\mathrm{P}<0,01)$ зростання рівня гормону, порівняно зі початком лактації (на 64,2\%). Подальші дослідження вірогідних змін не показали.

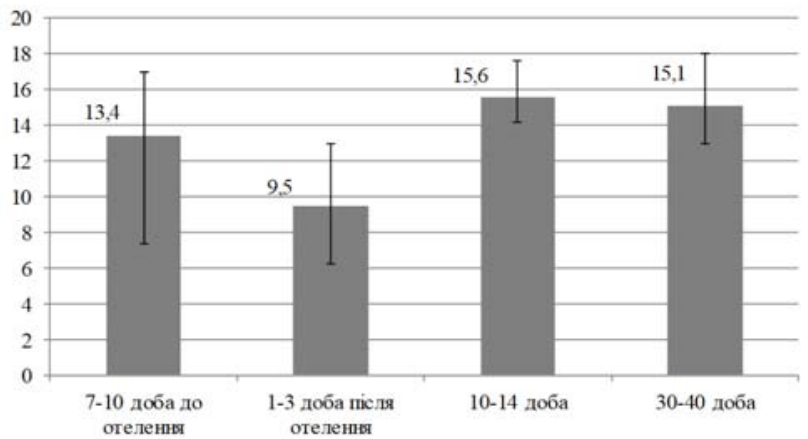

Рис. 2. Концентрація інсуліноподібного фактору росту у плазмі крові корів, нмоль/л; $\mathrm{n}=10$

Статистична обробка отриманого цифрового матеріалу показала існування середньої позитивної кореляційної залежності $(\mathrm{r}=0,5)$ між рівнем ІФР у плазмі крові та молозиві і сильної позитивну $(\mathrm{r}=0,7-0,8)$ між рівнем у плазмі крові та молоці.

\section{Обговорення}

Висока концентрація інсуліноподібного фактору росту у молозиві може бути пов'язана зі потребою стимулювання обмінних процесів у телят, оскільки в них на ранніх періодах постнатального онтогенезу ендокринна система $€$ незрілою. Позитивна кореляційна залежність між рівнем ІФР у молоці та плазмі крові свідчить про залежність безпечності отриманого молока від фізіологічного і клінічного стану тварини та доцільність подальших досліджень. Отримані нами результати рівня ІФР у молоці узгоджуються з даними інших дослідників (Malven et al., 1987; Sejrsen et al., 2001).

Широкі межі коливання показника в межах однієї групи тварин свідчать про індивідуальні особливості та підтверджують перспективу подальших досліджень.
На нашу думку, зниження рівня інсуліноподібного фактору росту у плазмі крові корів на початку лактації, враховуючи фізіологічні функції даного гормону, однозначно пояснити не можливо. За низького рівня соматомедину в крові секреція соматотропін-рилізинг гормону і соматотропіну зростає, за високого - знижується (Gkioka et al., 2015; Vigneri et al., 2015). Водночас ІФР регулює секрецію соматостатину, а саме: високий рівень інсуліноподібного фактору росту приводить до зростання секреції соматостатину, низький - до іï зниження. Але дія може бути загальмованою недостатнім поїданням корму, нечутливістю гормону росту, відсутністю реакції рецепторів або активністю сигнального шляху, нижчою за необхідний мінімум. Крім цього, було встановлено, що за нестачі ІФР в крові він може продукуватися в самих м'язах (Miura et al., 1992). Ще однією причиною може бути енергетичний дефіцит на початку лактаційного періоду. Крім цього, зниження рівня ІФР разом 3 низькою концентрацією тиреоїдних гормонів може бути одним 3 механізмів формування лактаційної домінанти (Simonov, 2013). Низький рівень даних гормонів дозволяє зменшити активність використання енергетичних сполук в тканинах тіла та підвищити їх доступність для молочної залози.

\section{Висновки}

Отриманий фактичний матеріал свідчить про те, що найвищий рівень ІФР реєструється у молозиві. Далі концентрація гормону вірогідно (Р < 0,01) знижується до 10-14 доби лактації. Високий рівень ІФР у молозиві може бути пов'язаний з необхідністю стимулювання метаболізму в телят у ранній постнатальний період онтогенезу.

У плазмі крові корів встановлено зниження рівня ІФР після отелення. Найвища концентрація відмічалася на 10-14 доби лактації. Зниження рівня інсуліноподібного фактору росту у плазмі крові корів на початку лактації, враховуючи фізіологічні функції даного гормону, однозначно пояснити неможливо. Це може бути пов'язано як з енергетичним дефіцитом чи фізіологічним станом тварин, так і 3 формуванням лактаційної домінанти та рівнем інших гормонів.

Перспектива подальших досліджень полягає у досліджені залежності рівня ІФР у секреті молочної залози від продуктивності, породи, віку та годівлі тварини.

\section{References}

Braak, B., Siezen, C., Speksnijder, E.N., Koedoot, E., van Steeg, H., Salvatori, D.C., van de Water, B. \& van der Laan, J.W. (2015). Mammary gland tumor promotion by chronic administration of IGF1 and the insulin analogue $\mathrm{AspB} 10$ in the $\mathrm{p} 53 \mathrm{R}^{270 \mathrm{H}^{++}}$WAPCre mouse model. Breast Cancer Res., 17, 14. doi: 10.1186/s13058-015-0518-y.

Duarte-Salles, T., Fedirko, V., Stepien, M., Trichopoulou, A., Bamia, C., Lagiou, P., Lukanova, A., Trepo, E., 
Overvad, K., Tjønneland, A., Halkjaer, J., BoutronRuault, M.C., Racine, A., Cadeau, C., Kühn, T., Aleksandrova, K., Trichopoulos, D., Tsiotas, K., Boffetta, P., Palli, D., Pala, V., Tumino, R., Sacerdote, C., Panico, S., Bueno-de-Mesquita, H.B., Dik, V.K., Peeters, P.H., Weiderpass, E., Torhild Gram, I., Hjartåker, A., Ramón Quirós, J., Fonseca-Nunes, A., MolinaMontes, E., Dorronsoro, M., Navarro Sanchez, C., Barricarte, A., Lindkvist, B., Sonestedt, E., Johansson, I., Wennberg, M., Khaw, K.T., Wareham, N., Travis, R.C., Romieu, I., Riboli, E., \& Jenab, M. (2014). Dairy products and risk of hepatocellular carcinoma: the European Prospective Investigation into Cancer and Nutrition. Int. J. Cancer, 135(7), 1662-1672. doi: $10.1002 / \mathrm{ijc} .28812$.

Frezza, V., Fierro, C., Gatti, E., Peschiaroli, A., Lena, A.M., Petruzzelli, M.A., Candi, E., Anemona, L., Mauriello, A., Pelicci, P.G., Melino, G., \& Bernassola, F. (2018). $\triangle$ Np63 promotes IGF1 signalling through IRS1 in squamous cell carcinoma. Aging (Albany NY), 10(12), 4224-4240. doi: 10.18632/aging.101725.

Frysaka, Z., Schovaneka, J., Iacoboneb, M., \& Karaseka, D. (2015). Insulin-like Growth Factors in a clinical setting: Review of IGF-I. Biomed Pap Med Fac Univ Palacky Olomouc Czech Repub., 159(3), 347-351. doi: $10.5507 / \mathrm{bp} .2015 .041$

Gkioka, E., Msaouel, P., \& Philippou, A. (2015). The role of insulin-like growth factor-1 signaling pathways in uterine leiomyoma. J. In Vivo, 29(6), 637-649. https://www.ncbi.nlm.nih.gov/pubmed/26546520.

Harrison, S., Lennon, R., Holly, J., Higgins, J.P.T., Gardner, M., Perks, C., Gaunt, T., Tan, V., Borwick, C., Emmet, P., Jeffreys, M., Northstone, K., Rinaldi, S., Thomas, S., Turner, S.D., Pease, A., Vilenchick, V., Martin, R.M., \& Lewis, S.J. (2017). Does milk intake promote prostate cancer initiation or progression via effects on insulin-like growth factors (IGFs)? A systematic review and meta-analysis. Cancer Causes Control, 28(6), 497-528. doi: 10.1007/s10552-017-0883-1.

Kim, J.W. (2014). Modulation of the somatotropic axis in periparturient dairy cows. Asian-Australas J. Anim. Sci., 27(1), 147-154. doi: 10.5713/ajas.2013.13139.

Kleinberg, D.L. \& Barcellos-Hoff, M.H. (2011). The pivotal role of insulin-like growth factor I in normal mammary development. Endocrinol Metab Clin North Am., 40(3), 461-471. doi: 10.1016/j.ecl.2011.06.001.

Malven, P., Head, H., Collier, R.J. \& Buonomo, F. (1987). Periparturient changes in secretion and mammary uptake of insulin and in concentrations of insulin and insulin-like growth factors in milk of dairy cows. J. Dairy Sci., 70(11), 2254-2265. doi: $10.3168 /$ jds.S0022-0302(87)80285-0.

Miura, Y., Kato, H., \& Noguchi, T. (1992). Effect of dietary proteins on insulin-like growth factor-1 (IGF1) messenger ribonucleic acid content in rat liver. The British journal of nutrition, 67(2), 257-265. https://www.ncbi.nlm.nih.gov/pubmed/1596498.

Nielsen, T.S., Purup, S., Wärri, A., Godschalk, R.W., \& Hilakivi-Clarke, L. (2011). Effects of maternal expo- sure to cow's milk high or low in isoflavones on carcinogen-induced mammary tumorigenesis among rat offspring. Cancer Prev Res (Phila), 4(5), 694-701. doi: 10.1158/1940-6207.CAPR-10-0220.

Park, S.W., Kim, J.Y., Kim, Y.S., Lee, S.J., Lee, S.D., \& Chung, M.K. (2014). A milk protein, casein, as a proliferation promoting factor in prostate cancer cells. World J Mens Health, 32(2), 76-82. doi: 10.5534/wjmh.2014.32.2.76.

Partridge, L., Alic, N., Bjedov, I., \& Piper, M.D. (2011). Ageing in drosophila: the role of the insulin/Igf and TOR signalling network. J. Exp Gerontol, 46(5), 376381. doi: 10.1016/j.exger.2010.09.003.

Rieunier, G., Wu, X., Macaulay, V.M., Lee, A.V., WeyerCzernilofsky, U., \& Bogenrieder, T. (2019). Bad to the Bone: The Role of the Insulin-Like Growth Factor Axis in Osseous Metastasis. Clin Cancer Res. doi: 10.1158/1078-0432.CCR-18-2697.

Rogers, I., Emmett, P., Gunnell, D., Dunger, D., \& Holly, J. (2006). Milk as a food for growth? The insulin-like growth factors link. Public Health Nutr., 9(3), 359-368. https://www.ncbi.nlm.nih.gov/pubmed/16684388.

Salmon, W.D., \& Daughaday, W.H. (1957). A hormonally controlled serum factor which stimulates sulfate incorporation by cartilage in vitro. J. Lab. Clin. Med., 49(6), 825-836. https://www.ncbi.nlm.nih.gov/pubmed/ 13429201.

Sejrsen, K., Pedersen, L.O., Vestergaard, M., \& Purup, S. (2001). Biological activity of bovine milk: Contribution of IGF-I and IGF binding proteins. Livestock Production $\quad$ Science, 70(1-2), 79-85. doi: 10.1017/S0022029906002093.

Simonov, M.R. (2013). Vmist gormoniv shhytopodibnoi' ta pryshhytopodibnoi' zaloz u plazmi krovi vysokoproduktyvnyh koriv na riznyh fazah laktacii' ta periodah utrymannja. Naukovo-tehnichnyj bjuleten' Instytut biologii' tvaryn ta DNDKI vetpreparativ ta kormovyh dobavok, 14(1-2), 59-62 (in Ukrainian).

Thornton, K.J., Kamange-Sollo, E., White M.E., \& Dayton, W.R. (2016). Active G protein-coupled receptors (GPCR), matrix metalloproteinases 2/9 (MMP2/9), heparin-binding epidermal growth factor (hbEGF), epidermal growth factor receptor (EGFR), erbB2, and insulin-like growth factor 1 receptor (IGF-1R) are necessary for trenbolone acetate-induced alterations in protein turnover rate of fused bovine satellite cell cultures. J. Anim. Sci., 94(6), 2332-2343. doi: $10.2527 /$ jas.2015-0178.

Um, C.Y., Fedirko, V., Flanders, W.D., Höflich, C., Wirthgen, E., \& Bostick R.M. (2017). Circulating insulin-like growth factor-related biomarkers: Correlates and responses to calcium supplementation in colorectal adenoma patients. Mol Carcinog, 56(9), 21272134. doi: 10.1002/mc.22669.

Vigneri, P.G., Tirrò, E., Pennisi, M.S., Massimino, M., Stella, S., Romano, C., \& Manzella, L. (2015). The insulin/IGF system in colorectal cancer development and resistance to therapy. J. Front Oncol., 5, 230. doi: 10.3389/fonc.2015.00230. 